\title{
Shift in diet composition of Indian mackerel Rastrelliger kanagurta - an analysis in relation to climate change
}

\author{
V. SUPRABA*, A. P. DINESHBABU, SUJITHA THOMAS, PRATHIBHA ROHIT, K. M. RAJESH \\ AND P. U. ZACHARIA* \\ ICAR-Central Marine Fisheries Research Institute, Mangalore Research Centre, P. B. No 244, Hoige Bazar \\ Mangalore, Karnataka - 575 001. India \\ ${ }^{*}$ ICAR-Central Marine Fisheries Research Institute, P. B. No. 1603, Ernakulam North P. O., Kochi - 682018 \\ Kerala. India \\ e-mail: suphareesh5@gmail.com
}

\begin{abstract}
The feeding regime of organisms depend on the plankton community structure which is being studied worldwide to assess the changes in marine ecosystem structure due to climate change or anthropogenic activities. An attempt is made here to study the seasonal and long term variation in feed composition of Indian mackerel over a period of 40 years and its relationship with sea surface temperature to elucidate structural changes in food composition if any over period of time and its relationship to the primary and secondary productivity in eastern Arabian Sea marine ecosystem. The diet study during 2011-2014 reported the domination of phytoplankton consisting of Coscinodiscus sp. consistently and the presence of macroplankton and fish larvae whereas the diet during 1960-1961 showed the dominance of zooplankton and copepods. It could be assumed that increase in sea surface temperature which resulted in dominance of phytoplankton community as reported elsewhere in the world is also observed in eastern Arabian Sea which is reflected in the diet regime of Indian mackerel. The results also indicate its facultative feeding behaviour by compensating the low value phytoplankton with high value macroplankton and hence can be considered as a resilient species with regard to climate change.
\end{abstract}

Keywords: Climate change, Diet, Marine ecosystem, Plankton, Rastrelliger kanagurta, Sea surface temperature

\section{Introduction}

Marine plankton forms the basis of productivity supporting large number of commercially important planktivores (Chassot et al., 2010) and plays essential roles in aquatic food webs and strongly influences bio-geochemical processes in the ocean (Falkowski et al., 1998). It has been observed that a substantial change in the marine ecosystem due to climate and human interferences has induced changes in the plankton abundance, distribution (O’Neil et al., 2012), phenology (Edward and Richardson, 2004) and species composition (Klais et al., 2011). Casini et al. (2008) has reported that large changes in plankton abundances may have serious effects on ecosystem functioning via bottom-up and top down effects cascading through the food webs.

Marine ecosystem changes are being continuously monitored with time series environmental data which is essential to understand any spatial or temporal changes due to global warming (Domingues et al., 2008). Changes in marine plankton may affect biogeochemical cycles, climate patterns, fisheries and the structure and function of marine ecosystems. Increase in sea surface temperature (SST) due to global warming has resulted in the recent global decrease in phytoplankton biomass (Boyce et al., 2010). Higher SST will lead to nutrient limitation of phytoplankton growth and reduced plankton productivity (Roemmich and McGowan, 1995) and a shift towards a phytoplankton assemblage dominated by small phytoplankton (Li et al., 2009). According to Lewandowska et al. (2014), the effect of ocean warming on marine plankton depends on the nutrient regime.

Increasing temperature might alter the importance of grazing as an increase in temperature strengthens predator-prey interactions (Hoekman, 2010). A shift in the food web structure was observed in the Baltic Sea towards more microbial, less energy-efficient food webs consisting of lower food quality and smaller sized organisms, which in combination with warming may lead to decreased availability of energy for grazing zooplankton and fish (Suikkanen et al., 2013). Studies conducted by Klauschies et al. (2012) on effects of warming on phytoplankton communities with different light intensities in the Baltic Sea projected that under high temperature and lower light levels a higher share of smaller phytoplankton is expected for the next decades. 
The changes in the plankton composition over the years due to climatic and other similar factors would also influence the feeding regime of organisms depending on them for their sustenance. Along the Karnataka coast, similar trends in increase of SST over the decades have been noticed. The rise is clearly obvious with an average SST of $27.7^{\circ} \mathrm{C}$ during the 1960 's to $28.1^{\circ} \mathrm{C}$ during 2011-2014, which could have led to changes in species composition.

The Indian mackerel Rastrelliger kanagurta, an important commercially exploited pelagic resource is basically planktivorous, feeding mostly on zooplankton. Most of the earlier studies on the food and feeding of the Indian mackerel have suggested mackerel to be a planktivore, feeding mostly on zooplankton especially copepods and occasionally resorting to bottom feeding. Reports on the occurrence of macroscopic organisms such as fish larvae and juveniles occasionally in the stomach of mackerel are also available (Venkataraman and Mukundan, 1971; James and Sanutha, 1976; Sivdas and Bhaskaran, 2009). In the present study, detailed analysis of the stomach contents of mackerel samples collected along Mangalore Coast in Karnataka during March 2011 to November 2014 has been reported and compared with the earlier studies and probable reasons for the changing patterns observed in the feeding has been discussed. An attempt has also been made to study the seasonal and long term variation in feed composition of $R$. kanagurta and its relationship with SST to elucidate the structural changes in food composition if any over the period of time and its relationship to the primary and secondary productivity in the marine ecosystem. The feed composition was also compared with the historical biological data available on the species in Karnataka.

\section{Materials and methods}

Sample collection

Random samples of $R$. kanagurta exploited by trawl nets, purseseines and indigenous traditional gears (Mattabale, Ranibale and hand trawl) were collected on a weekly basis from Mangalore Fishing Harbour during March 2011 to November 2014. A total of 6,575 numbers of specimens were used for the present study. Samples collected from different gear were pooled and the total length, weight, sex, stage of maturity and feeding condition were recorded. The total length ranged from 85 to $300 \mathrm{~mm}$ and the wet weight from 5 to $335 \mathrm{~g}$. For the gut study, 30 stomachs per month were analysed and the feeding intensity was estimated based on visual appearance of the stomach and volume of the food contents. The number and occurrence methods (Natarajan and Jhingaran, 1961) were followed for the analyses.
Time series data on sea surface temperature off Karnataka was procured from International Comprehensive Ocean-Atmosphere Data Set (ICOADS) website (http:// rda.ucar.edu). The monthly SST data procured was averaged to get yearly average from which the average SST for the period 2011-2014 was computed. The same was done for the average SST during 1960-1961.

\section{Statistical analysis}

The SIMPER analysis was used for finding out the similarity and dissimilarity of plankton composition between seasons. The CLUSTER analysis was used to find out the group clustering within seasons. Comparison of the diet composition was done to elucidate the changes if any in the feed composition following Noble (1962).

\section{Results}

Diet

The diet study of R. kanagurta during March 2011 to November 2014 revealed the feeding intensity of the mackerel as poor to moderate (Fig. 1). Detailed analysis of food contents showed that they fed predominantly on phytoplankton (Fig. 2) with diatoms dominating followed by dinoflagellates. Occurrence of diatoms in the gut content of mackerel was at its peak in July. Diatoms were represented by species of Coscinodiscus, Fragilaria, Rhizosolenia, Biddulphia, Chaetoceros, Skeletonema, Nitzschia, Planktoniella, Thalassiosira, Thalassiothrix, Melosira and Bacteriastrum. The main diatom that was observed to be dominant throughout the study period was the Coscinodiscus sp.

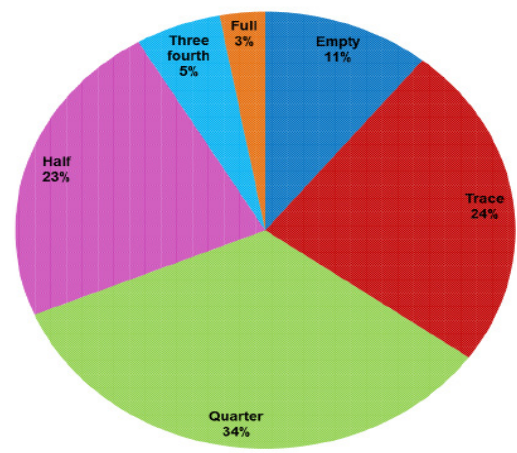

Fig. 1. Fullness of gut in mackerel

Dinoflagellates encountered in the gut were species of Ceratium, Triceratium, Peridinium, Protoperidinium, Ornithocercus, Dinophysis, Pyrophacus, Ditylum and Prorocentrum. Dinoflagellates in the mackerel gut were observed to be maximum in the month of September. Other than diatoms and dinoflagellates, blue green algae represented by species of Trichodesmium and Oscillatoria 


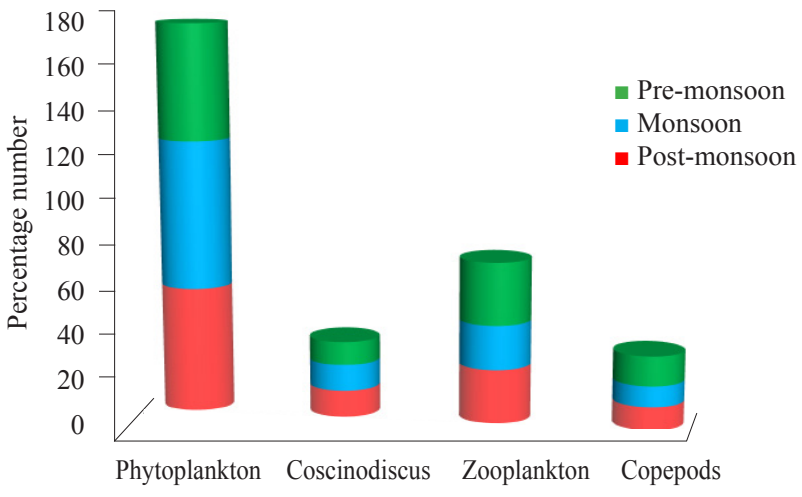

Fig. 2. Comparison of plankton in the gut content of mackerel during different seasons

were also present but comparatively in low proportion. The content of phytoplankton in the gut was high during monsoon season.

Zooplankton in the gut formed just half the percentage of phytoplankton and was observed to be high during post-monsoon months. Species of copepods representing the zooplankton were observed to range from 10-12 in percentage number during different seasons and dominated in the month of January. The percentage number of copepods was found to be less when compared to diatom Coscinodiscus sp. Fish eggs, bivalve larvae, amphipods, crustacean larvae, copepod eggs and cladocerans were the other zooplankton observed in mackerel gut.

A significant observation in the mackerel diet was the presence of macroplankton, pieces of squid and juveniles of fish in all the four years of study. The macroplankton consisted mainly of Acetes sp., Lucifer spp., squilla and fish larvae. Juveniles of fish observed during the analysis were that of Sardinella longiceps and Stolephorous, Leiognathus, Saurida, Bregmaceros and Nemipterus species. Both macroplankton as well as fish were observed to be high during the post-monsoon months. These macroorganisms formed a part of their diet during most months with predominance during April, May and June. Along with the various food items, the stomach also contained miscellaneous items like tintinids, foraminiferens, fish scales, crustacean remains, sand and organic debris. Table 1 shows the food composition in mackerel gut during different seasons from 2011-2014.

The diet of mackerel during 1960-1961 showed the dominance of zooplankton and copepods (Noble, 1962). Appendicularians, ctenophores, cirripede nauplii and cypris larvae were the other zooplankton encountered in the mackerel gut. The occurrence of diatoms in the gut content was at its peak in April but were practically absent in November and early December. Among the diatoms, Chaetoceros species formed the dominant food item in the gut. In the present study, mackerel diet showed the
Table 1. Percentage number of food items in the stomach of mackerel

\begin{tabular}{llll}
\hline Prey & PM & M & PoM \\
\hline Diatom & 39.9 & 40.75 & 34.1 \\
Dinoflagellate & 16.5 & 21.62 & 18.82 \\
Cyanobacteria & 1.85 & 2.61 & 1.73 \\
Copepod & 10.87 & 9.65 & 11.90 \\
Cladocera & 1.28 & 1.16 & 1.22 \\
Amphipod & 4.96 & 3.92 & 4.31 \\
Chaetognaths & 0.09 & 0 & 0.05 \\
Polychaete & 0.39 & 0.11 & 0.53 \\
Lucifer & 0.49 & 0.02 & 0.02 \\
Acetes sp. & 0.04 & 0 & 1.70 \\
Anchovy & 0.13 & 0.15 & 0 \\
Leiognathus sp. & 0.06 & 0.04 & 0 \\
Bregmaceros sp. & 0 & 0 & 0.23 \\
Nemipterus sp. & 0 & 0 & 0.5 \\
Oilsardine & 0 & 0 & 0.08 \\
Saurida sp. & 0.02 & 0 & 0 \\
Foaraminifera & 2.86 & 1.98 & 1.32 \\
Fish scales & 5.98 & 3.59 & 4.53 \\
Crustacean remains & 3.31 & 3.94 & 4.79 \\
Sand & 0.68 & 0.27 & 0 \\
Macroplankton & 0.83 & 0.33 & 2.86 \\
Digested matter & 1.10 & 1.85 & 1.81 \\
Digested fish & 0.31 & 0.23 & 0.30 \\
Tintinids & 1.40 & 2.06 & 1.93 \\
\hline PM - pre-monson & -19 &
\end{tabular}

PM - pre-monsoon; M - monsoon; PoM - post-monsoon

dominance and consistent occurrence of the phytoplankton Coscinodiscus sp.

\section{Trend in SST}

Increase in SST was observed in Karnataka waters over the years. The average SST along coastal Karnataka (Fig. 3) was $27.6^{\circ} \mathrm{C}$ during 1960-61 which increased to $28.1^{\circ} \mathrm{C}$ during $2011-2014$. The SST in $1960-1961$ was at its peak during April-May at about $29^{\circ} \mathrm{C}$. During the period of study, the SST was found to be at its maximum in the month of May with an increase of $0.1{ }^{\circ} \mathrm{C}$. Pre-monsoon season had the maximum SST which has

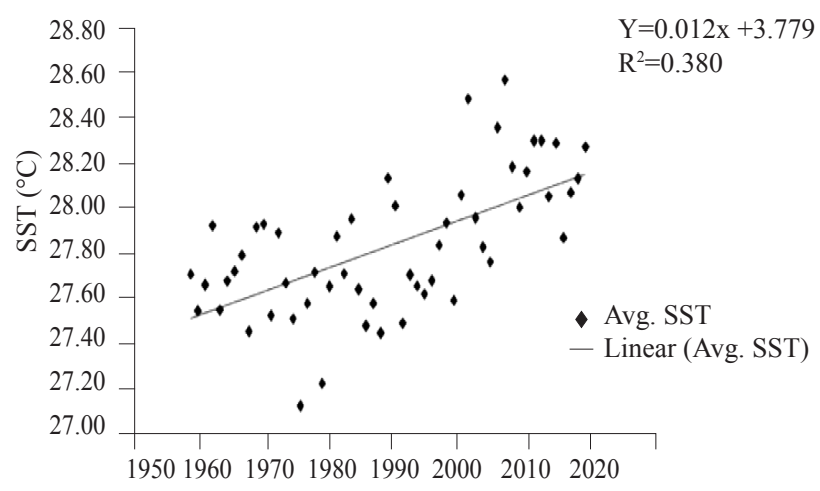

Fig. 3. Sea surface temperature (SST) in Karnataka waters (1960-2014) 
shown increase over the years. Increasing trend in SST was also observed in the monsoon as well as in the post-monsoon seasons (Fig. 4).

CLUSTER analysis showed that the pre-monsoon and monsoon season formed one cluster to which the post-monsoon season is linked (Fig. 5). SIMPER analysis showed that Coscinodiscus sp. and copepods contributed to the maximum similarity between seasons. Major groups contributing to the dissimilarity between seasons were Pyrophacus sp. and Ceratium sp. The pre-monsoon season had the highest temperature during the year which was found to be congenial for the plankton productivity and thereby contributing to the maximum diversity in the feed. The diet was dominated by phytoplankton during the period.

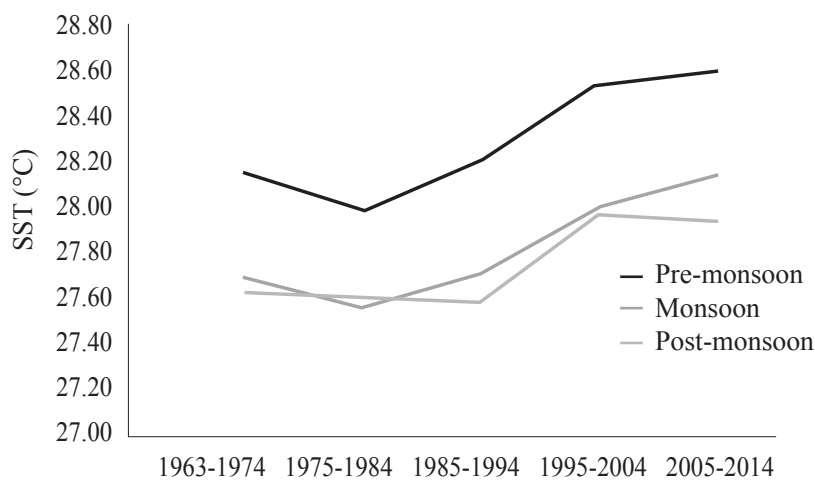

Fig. 4. SST in different seasons in Karnataka, India

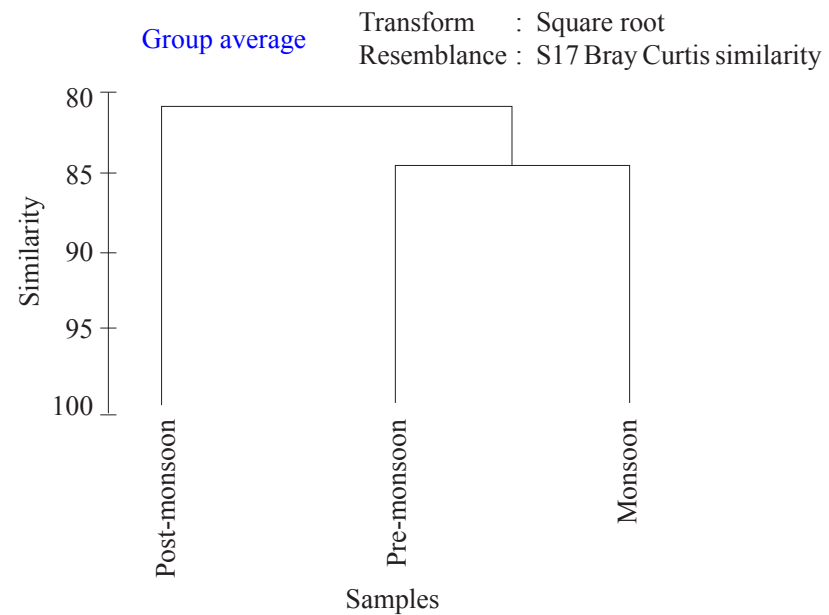

Fig. 5. Seasonal cluster analysis of diet composition of Indian mackerel

\section{Discussion}

Increasing trends in SST were observed off Karnataka waters from 1960-'61 to the study period. Marine phytoplankton contributes to nearly half of global productivity (Baumert and Petzoldt, 2008) and the rise in SST will alter the productivity as well as composition of marine plankton communities (Thomas et al., 2012). Studies have indicated that higher SST's lead to decrease in phytoplankton biomass (Roemmich and McGowan, 1995). The significant increase in SST observed off Karnataka waters would have increased the productivity of phytoplankton which is reflected in the diet composition of mackerel. At a regional scale, increase in SST has shown to increase the phytoplankton biomass in the Baltic Sea (Suikkanen et al., 2013) and in the North Sea (McQuatters-Gallop et al., 2007).

The zooplankton in the gut of mackerel was found to be half the percentage of phytoplankton during the study period. In the marine ecosystem, studies have shown that microzooplankton and mesozooplankton are the major consumers of phytoplankton (Somner, 2005) and are found to show differences and preferences to prey size (Hansen et al., 1994) which may change due to climatedriven shifts in the predator community composition (Heidi et al., 2010). Klauschies et al. (2012), reported that smaller phytoplankton are grazer controlled mainly by ciliates. Studies by Stiboret et al. (2004) indicated that the copepods switch to feed on ciliates due to increase in small size phytoplankton biomass and lack of preferred and high energy palatable food. But the large outbreak of jellyfish and ctenophores in the coastal waters worldwide due to climate and human induced changes (Purcell, 2005) has decreased the food for plankton eating fish populations by feeding on copepods, the major food source of fishes (Smith et al., 2008). Decrease in the population of copepods is evident in the diet of mackerel during the study period. Owing to the low energy content of small sized phytoplankton, it is probable that the mackerel tends to gain the loss by feeding on macroplankton and juveniles of fish. The study thus infers that even with global warming, mackerel has the capacity to substitute food with high energy value and modify its feeding habit depending on the availability of different organisms in the environment. It also supports the view on the facultative feeding habit of mackerel (James and Sanutha, 1976) and hence can be considered as one of the resilient species with regard to climate change.

\section{Acknowledgements}

Authors place on record their gratitude to the Ministry of Agriculture, Government of India for funding the study under the project National Innovations in Climate Resilient Agriculture (NICRA). The authors are also grateful to Dr. A. Gopalakrishnan, Director ICAR-CMFRI, Kochi for his constant support and encouragement. 


\section{References}

Boyce, D. G., Lewis, M. R. and Worm, B. 2010. Global phytoplankton decline over past century. Nature, 466: 591-596.

Baumert, H. Z. and Petzoldt, T. 2008. The role of temperature, cellular quota and nutrient concentrations for photosynthesis, growth and light-dark acclimation in phytoplankton. Limnologica, 38: $313-326$

Casini, M., Lovgren, J., Hjelm, J., Cardinale, M. and Molinero, J. C. 2008. Multilevel trophic cascades in a heavily exploited open marine ecosystem. Proc. R. Soc. B Biol. Sci., 275: 1793-1801.

Chassot, E., Bonhommeau, S., Dulvy, N. K., Melin, F. and Watson, R. 2010. Global marine primary production constrains fisheries catches. Ecol. Lett., 13: 495-505.

Domingues, C. M., Church, J. A., White, N. J., Gleckler, P. J. and Wijffels, S. E. 2008. Improved estimates of upperocean warming and multi-decadal sea-level rise. Nature, 453: 1090-1093.

Edwards, M. and Richardson, A. J. 2004. Impact of climate change on marine pelagic phenology and trophic mismatch. Nature, 430: 881-884.

Falkowski, P. G., Barber, R. T. and Smetacek, V. 1998. Biogeochemical controls and feedbacks on ocean primary production. Science, 281: 200-206.

Hansen, B., Bjornsen, P. K. and Hansen, P. J. 1994. The size ratio between planktonic predators and their prey. Limnol. Oceanogr., 39: 395-403.

Heidi, L. F. and Peter, J. S. F. 2010. Plankton community properties determined by nutrients and size-selective feeding. Mar. Ecol. Prog. Ser., 413: 1-15.

Hoekman, D. 2010. Turning up the heat: temperature influences the relative importance of top-down and bottom-up effects. Ecology, 91: 2819-2825.

James, P. S. B. R. and Santha Joseph, P. 1976. An instance of unusual feeding behaviour of the Indian mackerel, Rastrelliger kanagurta (Cuvier) off Mangalore. J. Bombay Nat. Hist. Soc., 73(3): 538-539.

Klais, R., Tamminen, T., Kremp, A., Spilling, K. and Olli, K. 2011. Decadal-scale changes of dinoflagellates and diatoms in the anomalous Baltic Sea spring bloom. PLOS ONE, 6(6): e21567. doi:10.1371/journal.pone.0021567.

Klauschies, T., Bauer, B., Aberle-Malzahn, N., Sommer, U. and Gaedke, U. 2012. Climate change effects on phytoplankton depend on cell size and food web structure. Mar. Biol., 159: $2455-2478$.

Lewandowska, A. M., Boyce, D. G., Hofmann, M., Matthiessen, B., Sommer, U. and Worm, B. 2014. Effects of sea surface warming on marine plankton. Ecol. Lett., 17(5): 614-623.
Li, W. K. W., McLaughlin, F. A., Lovejoy, C. and Carmack, E. C. 2009. Smallest algae thrive as the Arctic Ocean freshens. Science, 326(5952): p. 539. doi: 10.1126/science.1179798.

McQuatters-Gollop, A., Raitsos, D. E., Edwards, M., Pradhan, Y., Mee, L. D., Lavendar, S. J. and Attrill, M. J. 2007. A longterm chlorophyll data set reveals regime shift in North Sea phytoplankton biomass unconnected to nutrient trends. Limnol. Oceanogr., 52: 635-648.

Natarajan, A. V. and Jhingran, A. G. 1961. Index of preponderance - a method of grading the food elements in the stomach analysis of fishes. Indian J. Fish., 8(1): 54-59.

Noble, A. 1962. Food and feeding habits of the Indian mackerel, Rastrelliger kanagurta (Cuvier) at Karwar. Indian J. Fish., 9A(2): 701-713

O'Neil, J. M., Davis, T. W., Burford, M. A. and Gobler, C. J. 2012. The rise of harmful cyanobacteria blooms: the potential roles of eutrophication and climate change. Harmful Algae, 14: 313-334.

Purcell, J. E. 2005. Climate effects on formation of jellyfish and ctenophore blooms: A review. J. Mar. Biol. Ass. U. K., 85: 461-476.

Roemmich, D. and McGowan, J. 1995. Climate warming and the decline of zooplankton in the California. Curr. Sci., 267: 1324-1326.

Sivadas, M. and Bhaskaran, M. M. 2009. A note on the stomach content analysis of the Indian mackerel Rastrelliger kanagurta (Cuvier) from Calicut, Kerala. Indian J. Fish., 56(2): 143-146.

Smith, W., Steinberg, D., Bronk, D. and Tang, M. 2008. Marine plankton food webs and climate change. http:// estuaries.noaa.gov/teachers/pdf/Plankton_Food_Webs VIMS.pdf, p. 4.

Sommer, U. 2005. Biologische Meereskunde, $2^{\text {nd }}$ edn., Springer, Berlin, $412 \mathrm{pp}$.

Stibor, H., Vadstein, O., Diehl, S., Gelzleichter, A., Hansen, T. and Hantzsche, F. 2004. Copepods act as a switch between alternative trophic cascades in marine pelagic food webs. Ecol. Lett., 7: 321-328.

Suikkanen, S., Pulina, S., Engstrom-Ost, J., Lehtiniemi, M. and Lehtinen, S. 2013. Climate change and eutrophication induced shifts in northern summer plankton communities. PLOS ONE, 8(6): e66475. doi:10.1371/journal.pone.006 6475.

Thomas, M. K., Kremer, C. J., Klausmeier, C. A. and Litchman, E. 2012. A global pattern of thermal adaptation in marine phytoplankton. Science, 338: 1085-1088.

Venkataraman, G. and Mukundan, C. 1971. A note on the food of young mackerel. J. Mar. Biol. Ass. India, 12(1\&2): 230-231.

Date of Receipt $\quad: 06.11 .2015$

Date of Acceptance : : 08.04.2016 